The larger legal framework 


\title{
The constitutional framework for data access rights
}

\author{
Thomas Fetzer
}

\section{A. Introduction}

Looking at data access rights from the perspective of constitutional law, three categories of potential constitutional requirements need to be considered: Firstly, it must be examined whether any data access rights are derived from the constitution itself. Secondly, it should be considered whether the constitution obliges the legislature to regulate data access rights and enact respective statutory provisions. Thirdly and finally, the constitution must be examined regarding the limits it sets for the legislature if it considers the creation of statutory data access rights. Yet, given the inherent possibility that access to data encroaches on the fundamental rights of the individuals whose data is concerned, the latter question on potential limits for statutory data access rights is relevant regardless of whether the legislature is obliged or simply entitled to create data access rights.

When considering these potential constitutional requirements, a further distinction has to be made depending on who the access petitioner is and who the party obliged to grant access to data is. In the case of access to private data, the fundamental rights set the relevant framework. While fundamental rights can also play a role when access is to be granted to public sector data (e.g. insofar as industrial and business secrets or personal rights of third parties are affected) it is primarily state organisation law that will be relevant in these circumstances. It should also be noted that in the case of statutory data access rights under European Union (EU) law, the EU fundamental rights generally set the standard for legality, even though the German Federal Constitutional Court (Bundesverfassungsgericht) has just recently decided that the national fundamental rights can still apply as a fallback in these constellations. ${ }^{1}$

1 German Federal Constitutional Court, 5 May 2020, Case 2 BvR 859/15, (2020) Neue Juristische Wochenschrift 1647. 


\section{B. The relevant constitutional standard}

The substantive standard for all three abovementioned categories - constitutional data access rights, a legislative duty to enact statutory rights of data access and the constitutional limits of such statutory rights of data access - is primarily derived from the fundamental rights. This is true at least as long as the question of data access rights is not shaped by EU law, ${ }^{2}$ as the German Federal Constitutional Court has just recently emphasised once again in its decision on the right to be forgotten. ${ }^{3}$ From a procedural point of view, it is primarily the legislative competence that is of importance. In cases of private-access petitioners seeking access to data of private individuals, said legislative competence is most likely to be found in Article 74 No. 11 of the German Basic Law ('law relating to economic matters'). In contrast, if access is sought to public sector data, a distinction must be made between access to data held by federal institutions (Bund), the Federal States (Bundesländer) or municipal bodies (kommunale Einrichtungen).

\section{Constitutional data access rights?}

\section{Access to public sector data}

When asking whether data access rights can directly be derived from the constitution, it is self-evident that - if at all - this can only be relevant in cases in which private individuals desire access to public sector data. Given that the fundamental rights are primarily designed as rights of defense of the citizens against intrusions of the state, ${ }^{4}$ they consequently can only es-

2 German Federal Constitutional Court, 6 November 2019, Case 1 BvR 16/13, (2020) Neue Juristische Wochenschrift 300, para. 74 - Recht auf Vergessen I.

3 Regarding the relationship between the European Fundamental Rights Charter and the national fundamental rights see German Federal Constitutional Court, 22 October 1986, Case 2 BvR 197/83, (1987) Neue Juristische Wochenschrift 577 Solange II; German Federal Constitutional Court, 6 November 2019, Case 1 BvR 16/13, (2020) Neue Juristische Wochenschrift 300, paras 42-73 - Recht auf Vergessen I; German Federal Constitutional Court, 6 November 2019, Case 1 BvR 276/17, (2020) Neue Juristische Wochenschrift 314, paras 42-82 - Recht auf Vergessen II; German Federal Constitutional Court, 5 May 2020, Case 2 BvR 859/15, (2020) Neue Juristische Wochenschrift 1647.

4 German Federal Constitutional Court, 15 January 1958, Case 1 BvR 400/51, (1958) 7 Entscheidungen des Bundesverfassungsgerichts 198, 204-205 - Lüth; Horst Dreier, in Horst Dreier (ed.), Grundgesetz-Kommentar ( $3^{\text {rd }}$ edn, Mohr Siebeck 2013) 
tablish rights of data access for citizens against the state, but not for the government towards citizens or between citizens.

\section{Article 5(1), first sentence, alt. 2 of the Basic Law-freedom of information}

Constitutional data access rights are by no means unknown to the Basic Law. First and foremost, this is apparent from Article 5(1), first sentence of the Basic Law which guarantees the freedom of speech and the freedom of information. The latter gives citizens a right to inform themselves without hindrance from generally accessible sources. ${ }^{5}$ Admittedly, at first glance, it may seem surprising to refer to this provision when considering constitutional data access rights. While the primarily terminological divergence between access to 'information' and access to 'data' stipulates no significant substantive difference from a constitutional point of view, ${ }^{6}$ the seemingly disparate motivation for data access may be more troublesome: In the current debate on data access rights, the focus is oftentimes on the economic dimension of data and its significance for digital business models. The freedom of information as laid down in Article 5(1), first sentence, alt. 2 of the Basic Law, however, is traditionally associated with access to data as a prerequisite for the formation of opinions, political participation and thus ul-

Vor Art. 1 para. 84; Josef Isensee, 'Das Grundrecht als Abwehrrecht und staatliche Schutzpflicht' in Josef Isensee and Paul Kirchhof (eds), Handbuch des Staatsrechts, vol. IX ( $3^{\text {rd }}$ edn, C.F. Müller 2011) $\$ 191$ para. 17; Wolfram Höfling, in Michael Sachs (ed.), Grundgesetz Kommentar ( $8^{\text {th }}$ edn, C.H. Beck 2018) Vor Art. 1, paras 4245. This is referred to as the 'classical' function of the fundamental rights; see also German Federal Constitutional Court, 17 January 1957, Case 1 BvL 4/54, 6 Entscheidungen des Bundesverfassungsgerichts 55, 71; 12 May 1987, Case 2 BvR 1226/83, 76 Entscheidungen des Bundesverfassungsgerichts 1, 41; 1 December 2009, Case 1 BvR 2857/07, 125 Entscheidungen des Bundesverfassungsgerichts 39, 78.

5 German Federal Constitutional Court, 3 October 1969, Case 1 BvR 46/65, 27 Entscheidungen des Bundesverfassungsgerichts 71, 81 - Leipziger Volkszeitung; Helmut Schultze-Fielitz, in Horst Dreier (ed.), Grundgesetz-Kommentar ( $3^{\text {rd }}$ edn, Mohr Siebeck 2013) Art. 5 para. 76; Christoph Grabenwarter, in Roman Herzog and others (eds), Maunz/Dürig Grundgesetz Kommentar (90 ${ }^{\text {th }}$ edn, C.H. Beck 2020) Art. 5 paras 1014-1017; Edzard Schmidt-Jortzig, 'Meinungs- und Informationsfreiheit' in Josef Isensee and Paul Kirchhof, Handbuch des Staatsrechts, Vol. VII $\left(3^{\text {rd }}\right.$ edn, C.F. Müller 2009) $\$ 162$ para. 35.

6 On the general differences between the terms 'information' and 'data' see Friedrich Schoch, Informationsfreiheitsgesetz-Kommentar ( $2^{\text {nd }}$ edn, C.H. Beck 2016) \$2 paras 13, 17-21. 
timately democracy. ${ }^{7}$ This notwithstanding, in one of its few decisions on the freedom of information the German Federal Constitutional Court held:

Accordingly, two components are essential for the freedom of information guaranteed in Article 5(1), first sentence, of the Basic Law. One is the relevance for the democratic principle of Article 20(1) of the Basic Law: A democratic state cannot exist without a free and well-informed public opinion. In addition, the freedom of information has a component of an individual right derived from Article 1 and Article 2(1) of the Basic Law. It is one of the elementary needs of human beings to obtain information from as many sources as possible, to expand their own knowledge and thus to develop as a personality. In addition, in modern industrial society, the possession of information is of essential importance for the social position of the individual. ${ }^{8}$

In this context, the economic position of individuals can certainly be understood as an important aspect of their social position. Thus, even though the German Federal Constitutional Court puts a special emphasis on the democratic relevance of the freedom of information, the quoted passage at least supports the conclusion that seeking access to public sector data for purely economic reasons does not fall outside the scope of protection of the freedom of information.

However, while Article 5(1), first sentence, alt. 2 of the Basic Law may therefore, in substance, also cover an individual's access to public sector data where such access is not primarily politically motivated, it is the prevailing opinion of courts but also of academics that the provision does not contain a direct constitutional data access right to public sector data: ${ }^{9}$ Article 5(1), first sentence, alt. 2 of the Basic Law is a fundamental right

7 German Federal Constitutional Court, 3 October 1969, Case 1 BvR 46/65, 27 Entscheidungen des Bundesverfassungsgerichts 71, 81 - Leipziger Volkszeitung; Franz Schemmer, in Volker Epping and Christian Hillgruber (eds) Beck-OnlineKommentar Grundgesetz (43 ${ }^{\text {th }}$ edn, C.H. Beck 2020) Art. 5 GG para. 23; Christian Starck and Andreas L. Paulus, in Peter M. Huber and Andreas Voßkuhle (eds), von Mangoldt/Klein/Starck Grundgesetz Kommentar ( $7^{\text {th }}$ edn, C.H. Beck 2018) Art. 5 para. 102; Schultze-Fielitz (n. 5)) Art. 5 para. 76; Schmidt-Jortzig (n. 5) $\$ 162$ para. 33; Grabenwarter (n. 5) Art. 5 (1), (2) para. 985.

8 German Federal Constitutional Court, 3 October 1969, Case 1 BvR 46/65, 27 Entscheidungen des Bundesverfassungsgerichts 71, 81 - Leipziger Volkszeitung.

9 German Federal Constitutional Court, 24 January 2001, Case 1 BvR 2623/95, 103 Entscheidungen des Bundesverfassungsgerichts 44, 59-60 - Gerichtsfernsehen; Grabenwarter (n. 5) Art. 5(1), (2) paras 1011, 1023; Schemmer (n. 7) Art. 5 GG 
defined and shaped by statutory law. ${ }^{10}$ It only protects access to information that is generally accessible. This, however, is only the case where the source in question is suitable and intended to provide information to the general public. ${ }^{11}$ The intended use, i.e. the question which public sector information should be accessible to the general public, initially must be determined by the legislature. ${ }^{12}$ Accordingly, the substantive scope of protection of the freedom of information is not concerned if the legislature does not provide for a corresponding legal provision declaring a source to be publicly available, e.g. by creating data access rights. Certainly, this does not enable the legislature to completely undermine Article 5(1), first sentence, alt. 2 of the Basic Law by never opening up any information to the public and keeping all public sector information secret. ${ }^{13}$ Consequently, the German Federal Constitutional Court has also held that at least subsidiary data access rights may be derived directly from the constitution. ${ }^{14}$ Nonetheless, as described above, Article 5(1), first sentence, alt. 2 of the Ba-

para. 32; Herbert Bethge, in Michael Sachs (ed.) Grundgesetz Kommentar ( $8^{\text {th }}$ edn, C.H. Beck 2018) Art. 5 para. 59a; Karl-E. Hain, 'Verfassungsrecht' in Gerald Spindler and Fabian Schuster (eds), Recht der elektronischen Medien (4 ${ }^{\text {th }}$ edn, C.H. Beck 2019) Teil 1 C. para. 24.

10 On the necessity of legislative design of some fundamental rights Ingo von Münch and Philip Kunig, in Ingo von Münch and Philip Kunig (eds), Grundgesetz-Kommentar ( $6^{\text {th }}$ edn, C.H. Beck 2012) Vor Art. 1 para. 33; cf. Dreier (n. 4) Vor Art. 1 para. 107. Relating to Art. 5 cf. Schemmer (n. 7) Art. 5 GG para. 26.1; Hain (n. 9) Teil 1 C. para. 20; Dieter Dörr, in Detlef Merten and Hans-J. Papier (eds), Handbuch der Grundrechte, Vol. IV (C.F. Müller 2011) \$103 para. 30; see also German Federal Constitutional Court, 24 January 2001, Case 1 BvR 2623/95, 103 Entscheidungen des Bundesverfassungsgerichts 44, 60-Gerichtsfernsehen.

11 German Federal Constitutional Court, 3 October 1969, Case 1 BvR 46/65, 27 Entscheidungen des Bundesverfassungsgerichts 71, 83 - Leipziger Volkszeitung; 9 February 1994, Case 1 BvR 1687/92, 90 Entscheidungen des Bundesverfassungsgerichts 27, 32 - Parabolantenne; 24 January 2001, Case 1 BvR 2623/95, 103 Entscheidungen des Bundesverfassungsgerichts 44, 60 - Gerichtsfernsehen; Bethge (n. 9) Art. 5 para. 55; for further reference see also Rudolf Wendt, in Ingo von Münch and Philip Kunig (eds), Grundgesetz-Kommentar (6 ${ }^{\text {th }}$ edn, C.H. Beck 2012) Art. 5 para. 23; Dörr (n. 10) $\$ 103$ para. 27.

12 Schemmer (n. 7) Art. 5 para. 26.1; Hain (n. 9) Teil 1 C. para. 23; Dörr (n. 10) $\$ 103$ para. 30. See also German Federal Constitutional Court, 24 January 2001, Case 1 BvR 2623/95, 103 Entscheidungen des Bundesverfassungsgerichts 44, 60-61 Gerichtsfernsehen.

13 Cf. Bethge (n. 9) Art. 5 para. 57.

14 Cf. German Federal Constitutional Court, 20 June 2017, Case 1 BvR 1978/13, (2017) Neue Zeitschrift für Verwaltungsrecht, 1618, para. 20; Bethge (n. 9) Art. 5 paras 56a, 57. 
sic Law does not provide for a general right to access all public sector data. ${ }^{15}$ If, however, the legislature decides to create general or specific statutory access rights to public sector data, these statutory rights may be subject to the protection of Article 5(1), first sentence, alt. 2 of the Basic Law and therefore no longer be revoked without cause. ${ }^{16}$

\section{Article 2(1) of the Basic Law-general right of personality}

Regarding personal data, on the other hand, the German Federal Constitutional Court has indeed acknowledged constitutional data access rights independent of corresponding statutory rights. ${ }^{17}$ Such rights against the state can arise from the general right of personality and accompany the right to informational self-determination or render it more effective, as self-determination requires knowledge of who possesses what information about a specific person. ${ }^{18}$ While constitutional law primarily obliges the legislature

15 See references in n. 9; contrary Jürgen Kühling, in Hubertus Gersdorf and Boris P. Paal (eds), Beck-Online-Kommentar Informations- und Medienrecht ( $28^{\text {th }}$ edn, C.H. Beck 2020) Art. 5 GG para. 42.

16 Cf. Bethge (n. 9) Art. 5 paras 56a, 57; German Federal Constitutional Court, 20 May 2017, Case 1 BvR 1978/13, (2017) Neue Zeitschrift für Verwaltungsrecht, 1618, para. 20; 24 January 2001, Case 1 BvR 2623/95, 103 Entscheidungen des Bundesverfassungsgerichts 44, 60, 61 - Gerichtsfernsehen. Differently, Schemmer (n. 7 ) Art. 5 para. 27.1; Schultze-Fielitz (n. 5) Art. 5 para. 79.

17 In general, Schoch (n. 6) Einleitung paras. 74-75; Udo Di Fabio, in Roman Herzog and others (eds), Maunz/Dürig Grundgesetz Kommentar $\left(90^{\text {th }}\right.$ edn, C.H. Beck 2020) Art. 2 GG para. 178; German Federal Constitutional Court, 9 January 2006, (2006) Neue Juristische Wochenschrift 1116, paras 20-23; 17 July1991, Case 2 BvR 1570/89, (1991) Beck-online Rechtsprechung 06917. On the right to know one's ancestry German Federal Constitutional Court, 31 January 1989, Case 1 BvL 17/87, 79 Entscheidungen des Bundesverfassungsgerichts 256, 269; 6 May 1997, Case 1 BvR 409/90, 96 Entscheidungen des Bundesverfassungsgerichts 56, 63; 12 February 2007, Case 1 BvR 421/05, 117 Entscheidungen des Bundesverfassungsgerichts 202, 225-226; cf. also German Federal Constitutional Court, 9 April 2003, Case 1 BvR 1724/01, 108 Entscheidungen des Bundesverfassungsgerichts 82, 105. On the right to know public information measures German Federal Constitutional Court, 15 January 2008, Case 1 BvR 2/04, 120 Entscheidungen des Bundesverfassungsgerichts 31, 360-361.

18 Schoch (n. 6) Einleitung paras 74-75; Dreier (n. 4) Art. 2(1) para. 95; German Federal Constitutional Court, 15 December 1983, Case 1 BvR 209/83, 65 Entscheidungen des Bundesverfassungsgerichts 1, 43-46 - Volkszählung; 15 January 2008, Case 1 BvR 2/04, 120 Entscheidungen des Bundesverfassungsgerichts 31, 360-361; Rhineland-Palatinate Constitutional Court, 4 November 1998, Case 
to create statutory data access rights in this regard, ${ }^{19}$ citizens can request access to their personal data directly on the basis of Article 2(1) of the Basic Law if the legislature does not fulfil its responsibility. ${ }^{20}$ However, this shall not be discussed in further detail, in particular given that the EU has enacted corresponding provisions in the General Data Protection Regulation (GDPR). ${ }^{21}$

\section{Interim result}

Although the constitution provides for data access rights of citizens against the government, these rights are only rudimentary or conditional: In the case of Article 5(1), first sentence, alt. 2 of the Basic Law, they require an initial legislative decision on data access. The general right of personality, on the other hand, only becomes relevant if the legislature does not fulfil its obligation to enact statutory data access rights, and it only concerns personal data as opposed to machine or other non-personal data.

\section{Constitutional duty to create statutory data access rights?}

Given that no general data access rights can be derived from the constitution directly, the question arises whether the constitution imposes a duty on the legislature to create statutory data access rights. In this context, a distinction must be made between data access claims of citizens against the

B 5-98, (1999) Neue Juristische Wochenschrift 2264; German Federal Constitutional Court, 10 March 2008, Case 1 BvR 2388/03, 120 Entscheidungen des Bundesverfassungsgerichts 351, 360-362.

19 German Federal Constitutional Court, 15 December 1983, Case 1 BvR 209/83, 65 Entscheidungen des Bundesverfassungsgerichts 1, 44 - Volkszählung; 10 March 2008, Case 1 BvR 2388/03, 120 Entscheidungen des Bundesverfassungsgerichts 351, 359, 363. See also German Federal Constitutional Court, 19 October 2000, Case 1 BvR 586/90, (2001) Neue Zeitschrift für Verwaltungsrecht 185; 12 April 2005, Case 2 BvR 1027/02, 113 Entscheidungen des Bundesverfassungsgerichts 29, 58.

20 See references in n. 17. Cf. also Hubertus Gersdorf, in Hubertus Gersdorf and Boris P. Paal (eds), Beck-Online-Kommentar Informations- und Medienrecht $\left(28^{\text {th }}\right.$ edn, C.H. Beck 2020) Art. 2 GG para. 81.

21 See Art. 15 GDPR, which includes the right to receive a complete copy of the personal data undergoing processing. 
government on the one hand and data access claims of private individuals against one another.

\section{Right of access to public sector data}

As far as a potential citizen's claims of data access against the government are concerned, it should, first, be noted that a number of relevant statutes have been adopted over the past 25 years or so. At the federal level, these include the Freedom of Information Act (Informationsfreiheitsgesetz), ${ }^{22}$ the Consumer Information Act (Verbraucherinformationsgesetz), ${ }^{23}$ the Environmental Information Act (Umweltinformationsgesetz), ${ }^{24}$ the Act on the Re-use of Public Sector Information (Informationsweiterverwendungsgesetz) ${ }^{25}$ and the Geodata Access Act (Geodatenzugangsgesetz). ${ }^{26}$ It must be noted, however, that these statutes are not the result of a constitutional obligation. Instead, they are essentially either the consequences of a changed understanding of how transparent the actions of the government should be, ${ }^{27}$ or they are determined by EU law, for which the transparency of sovereign actions plays a different role, particularly for legitimising supranational actions. ${ }^{28}$ In fact, there is hardly any link in the Basic Law to an obligation of the government to establish rights of access to public sector information.

22 Freedom of Information Act (Informationsfreiheitsgesetz) of 15 September 2005, (2005) Bundesgesetzblatt I 2722.

23 Consumer Information Act (Verbraucherinformationsgesetz) of 5 November 2007, (2007) Bundesgesetzblatt I 2166, 2725.

24 Environmental Information Act (Umweltinformationsgesetz) of 6 November 2014, (2014) Bundesgesetzblatt I 1643.

25 Act on the Re-use of Public Sector Information (Informationsweiterverwendungsgesetz) of 13 December 2006, (2006) Bundesgesetzblatt I 2913.

26 Geodata Access Act (Geodatenzugangsgesetz) of 10 February 2009, (2009) Bundesgesetzblatt I 278.

27 Grabenwarter (n. 5) Art. 5(1), (2) para. 1011; Kühling (n. 15) Art. 5 GG paras 42, 43; Sonja Wirtz and Stefan Brink, 'Die verfassungsrechtliche Verankerung der Informationszugangsfreiheit', (2015) Neue Zeitschrift für Verwaltungsrecht 1166.

28 Directive 2003/4/EC of the European Parliament and the Council of 28 January 2003 on public access to environmental information and repealing Council Directive 90/313/EEC [2003] OJ L41/26; Directive 2003/98/EC of the European Parliament and the Council of 17 November 2003 on the re-use of public sector information [2003] OJ L345/90; Directive 2007/2/EC of the European Parliament and the Council of 14 March 2007 establishing an Infrastructure for Spatial Information in the European Community (INSPIRE) [2007] OJ L108/1; Schultze-Fielitz (n.) Art. 5 para. 21. 
Although Article 5(1), first sentence, alt. 2 of the Basic Law could theoretically serve as an indication of such a legislative duty, it already has been demonstrated that this provision neither establishes a direct constitutional right of access nor an obligation for the legislature to create statutory access rights. ${ }^{29}$ On the contrary, it is clear from the above that only where the legislature enacts statutory access rights they will be protected by the freedom of information and can thus not be abolished without cause. ${ }^{30}$

\section{Right of access to private data}

Even if the Basic Law does not provide for a legislative duty to create data access rights for citizens towards the government, the question remains whether the fundamental rights can stipulate a legislative duty to create rights of private individuals against one another. In this context, the article will only deal with access to non-personal data, not only because this volume contains a separate chapter on personal data; ${ }^{31}$ but also because it is important to consider non-personal data separately. To put it another way: Regarding the question of access to data exclusively from a protection of personal rights point of view would neglect the fact that non-personal data can also enjoy constitutional protection. ${ }^{32}$

The idea that fundamental rights can also oblige the legislature to create statutory protection measures for the legal relationship between private individuals is well established under constitutional law. ${ }^{33}$ Decisions to this

29 German Federal Constitutional Court, 24 January 2001, Case 1 BvR 2623/95, Entscheidungen des Bundesverfassungsgerichts 103, 44 - Gerichtsfernsehen; Schemmer (n. 7 ) Art. 5 para. 32; Schultze-Fielitz (n. 5) Art. 5 para. 244; Schoch (n. 6) Einleitung para. 73.

30 See references at n. 16 .

31 See Indra Spiecker gen. Döhmann, 'The legal framework for access to data from a data protection viewpoint - especially under GDPR', in this volume.

32 Cf. Thomas Wischmeyer and Eva Herzog, 'Daten für alle? - Grundrechtliche Rahmenbedingungen für Datenzugangsrechte' (2020) Neue Juristische Wochenschrift 288; Peter Axer, in Volker Epping and Christian Hillgrupber (eds), BeckOnline-Kommentar Grundgesetz (43 ${ }^{\text {th }}$ edn, C.H. Beck 2020) Art. 14 para. 50; Joachim Wieland, in Horst Dreier (ed.), Grundgesetz-Kommentar ( $3^{\text {rd }}$ edn, Mohr Siebeck 2013) Art. 14 para. 72.

33 Di Fabio (n. 17) Art. 2 para. 135; Hans-J. Papier and Foroud Shirvani, in Roman Herzog and others (eds), Maunz/Dürig Grundgesetz Kommentar $\left(90^{\text {th }}\right.$ edn, C.H. Beck 2020) Art. 14 para. 133; Eckart Klein, 'Grundrechtliche Schutzpflicht des Staates', (1989) Neue Juristische Wochenschrift 1633. 
effect can already be found in the very early case law of the German Federal Constitutional Court, particularly in connection with the right of physical integrity under Article 2(2) of the Basic Law (in some cases in conjunction with Article 1(1) of the Basic Law). ${ }^{34}$ The extensive statutory data protection regulations for the processing of private individuals' personal data by other private parties can also be understood as the result of a governmental duty to protect said private individuals from intrusions on their right of informational self-determination by other private individuals. ${ }^{35}$ Moreover, a legislative duty to enact statutes to protect the secrecy of telecommunications from infringements by private parties is derived from Article 10 of the Basic Law. ${ }^{36}$ These constitutional obligations to protect have three requirements in common: Firstly, a constitutionally protected legal interest is at stake. Secondly, this legal interest is threatened by private parties in a way that is equivalent to governmental restrictions in its effects. And thirdly, the endangered individuals are not in a position to protect themselves effectively without further legal protection and are, therefore, in need of legal protection. ${ }^{37}$

Based on this case law, one could try to argue that a legislative duty to enact data access rights for private petitioners towards other private individuals could be justified on the grounds that: Firstly, access to data is of-

34 German Federal Constitutional Court, 7 July 1971, Case 1 BvR 765/66, (1971) Neue Juristische Wochenschrift 2163; 30 November 1988, Case 1 BvR 1301/84, 79 Entscheidungen des Bundesverfassungsgerichts 174; 14 January 1981, Case 1 BvR 612/72, 56 Entscheidungen des Bundesverfassungsgerichts 54; 29 October 1987, Case 2 BvR 624/83, 77 Entscheidungen des Bundesverfassungsgerichts 170; 28 January 1992, Case 1 BvR 1025/82, 85 Entscheidungen des Bundesverfassungsgerichts 191.

35 German Federal Constitutional Court, 15 December 1983, Case 1 BvR 209/83, 65 Entscheidungen des Bundesverfassungsgerichts 1 - Volkszählung; 9 March 1988, Case $1 \mathrm{BvL}$ 49/86, 78 Entscheidungen des Bundesverfassungsgerichts 77, 84; 8 July 1997, Case 1 BvR 2111/94, 96 Entscheidungen des Bundesverfassungsgerichts 171, 181; 12 December 2000, Case 2 BvR 1741/99, 103 Entscheidungen des Bundesverfassungsgerichts 21, 31; 12 April 2005, Case 2 BvR 1027/02, 113 Entscheidungen des Bundesverfassungsgerichts 29, 46; 17 July 1984, Case 2 BvE 11/83, 67 Entscheidungen des Bundesverfassungsgerichts 100; Dreier (n. 4) Art. 2(1) para. 79.

36 German Federal Constitutional Court, 2 March 2010, Case 1 BvR 256/08, 125 Entscheidungen des Bundesverfassungsgerichts 260.

37 German Federal Constitutional Court, 31 May 2006, Case 2 BvR 1673/04, 116 Entscheidungen des Bundesverfassungsgerichts 116, 69; Christoph Degenhart, in Michael Sachs (ed.), Grundgesetz Kommentar (8 ${ }^{\text {th }}$ edn, C.H. Beck 2018) Art. 70 para. 63. 
tentimes essential for an individual's economic activity, i.e. the exercise of private autonomy and the freedom of occupation protected by fundamental rights. Secondly, this freedom is frequently restricted by private individuals in a way that is comparable with governmental restrictions, e.g. if private players accumulate large amounts of data and refuse access to private third parties. Thirdly, such private third parties cannot effectively defend themselves against this intrusion on their fundamental rights and must, therefore, be protected by statutory data access rights that can, ultimately, be enforced in court. In my opinion, the idea of a general data access right based on such a constitutional interpretation must be rejected: An understanding of the constitution such that it provides for a general duty to protect data access in private relationships, and which ultimately would demand the creation of data access rights, would not adequately balance the fact that the owner of the data in question - also being a private individual - enjoys protection by fundamental rights as well. ${ }^{38}$ This is true even though there is currently no data property right or comparable ancillary right that would fall within the scope of protection of the property rights under Article 14(1) of the Basic Law. ${ }^{39}$ Yet, in many cases, the 'owners' of data to which access is sought have acquired said data as part of their past professional activity and will want to use it for their professional activity in the future. This generally triggers protection by the freedom of occupation under Article 12 of the Basic Law. Even if this were not the case, the data owner would still be protected by the general freedom of personality of Article 2(1) of the Basic Law. This protection might not be particularly strong from a constitutional point of view, but - in my view - it would in any case prohibit a general right of access to data and thus a corresponding state duty to establish and regulate such a right. In this context, it should be borne in mind that the premature creation of data access rights can also have a negative impact on innovation in data-based business models, given

38 Cf. Wischmeyer and Herzog (n. 32).

39 Cf. Josef Drexl, 'Neue Regeln für die Europäische Datenwirtschaft?' (2017) Neue Zeitschrift für Kartellrecht 339; Jutta Stender-Vorwachs and Hans Steege, 'Wem gehören unsere Daten?' (2018) Neue Juristische Online-Zeitschrift 1361; Simon Adam, 'Daten als Rechtsobjekte' (2020) Neue Juristische Wochenschrift 2063; Wibke Werner, 'Schutz durch das Grundgesetz im Zeitalter der Digitalisierung' (2019) Neue Juristische Online-Zeitschrift 1041; Lothar Determann, 'Gegen Eigentumsrechte an Daten' (2018) Zeitschrift für Datenschutz 503; regarding data ownership Karl-Heinz Fezer, 'Dateneigentum - Theorie des immaterialgüterrechtlichen Eigentums an verhaltensgenerierten Personendaten der Nutzer als Datenproduzenten' (2017) Zeitschrift für IT-Recht und Recht der Digitalisierung 3 . 
the negative influence on the investment incentives of all market participants. ${ }^{40}$ This also needs to be considered in the constitutional context.

Even though the legislature, therefore, does not have a general constitutional duty to create statutory data access rights, it still must be considered whether such a duty can arise in extraordinary situations. Such a situation is inter alia conceivable in case of the emergence of private data monopolies which are capable of permanently eliminating competition in markets in which data is an essential input factor. Even if the refusal to give access to data is in principle protected by the monopolist's freedom of occupation, ${ }^{41}$ it is obvious that from a constitutional point of view the legislature would be allowed to impose restrictions on that right of the monopolist in order to protect competition. ${ }^{42}$ This could possibly also encompass a statutory right to data access. However, it does not seem impossible that the authority to enact statutes to protect competition may convert to a legislative duty to act if competition becomes permanently and effectively impossible without respective data access rights. In this context, it should clearly be noted that such a legislative duty should only be seen as an ultima ratio. It can only manifest where markets are no longer contestable in the longterm without respective data access rights, in such a way that it becomes effectively and structurally impossible for other holders of fundamental rights to exercise their economic freedoms.

\section{Interim result}

As a further interim result, the fundamental rights do not stipulate any general duty for the legislature to enact data access rights. This is true of the access to public sector data as well as of the data of private individuals. However, a fundamental duty to create data access rights that safeguard competition should be considered when the control over data leads to a

40 Cf. Martin Peitz and Heike Schweitzer, 'Ein neuer europäischer Ordnungsrahmen für Datenmärkte?' (2018) Neue Juristische Wochenschrift 275, 276; Heike Schweitzer, 'Datenzugang in der Datenökonomie: Eckpfeiler einer neuen Informationsordnung' (2019) Gewerblicher Rechtsschutz und Urheberrecht 569, 571. In general see also Thomas Fetzer, Staat und Wettbewerb in dynamischen Märkten (Mohr Siebeck 2013) 215.

41 Similar Wischmeyer and Herzog (n. 32) 292.

42 Cf. Rupprecht Podszun and Stefan Kreifels, 'Ministererlaubnis und Verfahrensrecht' in Christian Kersting and Rupprecht Podszun (eds), Die 9. GWB-Novelle (C.H. Beck 2017), ch. 14 para. 46. 
permanent and far-reaching exclusion of competition, i.e. when markets are not contestable and the exercise of economic freedoms becomes impossible for other market participants.

\section{E. Constitutional limits for data access rights?}

If, in summary, there is no legislative duty to create data access rights but - depending on the circumstances - an authority to enact statutory data access rights, the question arises to what extent the Basic Law sets any limits for the establishment of such rights. In this context, it should be noted that from a constitutional point of view the general authority of the legislature to establish these rights is not in doubt. To answer the question regarding the limits of this authority, a distinction must again be made between data access rights for the government in relation to private data on the one hand and data access rights between private individuals on the other.

\section{Data access rights of the government}

If the government desires access to data of private individuals, this triggers the protection by the fundamental rights in their traditional capacity as defensive rights, requiring a justification for every state attributed restriction of a protected freedom. ${ }^{43}$ Again, it should be emphasised that this also applies to non-personal data. Depending on the specific design of data access rights, the economic rights of Articles 12 (freedom of occupation), 14 (freedom of property) and 2(1) (general freedom of action) of the Basic Law will be relevant.

Against the background of the above, rights of access of the state to data are only permissible where they are founded on a statutory legal basis and if they are proportionate. This means they must pursue a legitimate goal

43 Dreier (n. 4) Vor. Art. 1 GG para. 84; Isensee (n. 4) $\$ 191$ para. 2; cf. also von Münch and Kunig (n. 10) Vor. Art. 1 GG paras 11-12; cf. German Federal Constitutional Court, 15 January 1958, Case 1 BvR 400/51, 7 Entscheidungen des Bundesverfassungsgerichts 198, 204-205 - Lüth; 6 January 1957, Case 1 BvR 253/56, 6 Entscheidungen des Bundesverfassungsgerichts 32, 41 - Elfes. 
and have to be suitable, necessary and appropriate in relation to said goal. ${ }^{44}$ The mere fact that private individuals have access to data that is useful for the government or for the general public is not sufficient to establish a proportionate restriction of the fundamental freedoms of the data owner. Although no court decisions have yet been published in this specific context, it can be deduced from the case law of the German Federal Constitutional Court on the involvement of private parties to fulfil public tasks (Indienstnahme Privater) that the government cannot demand access to private resources in the fulfilment of its public duties simply by reason that said resources are at the disposal of a private party. On the contrary, it is required that said private party has a special responsibility or ability for achieving the public purpose, which can particularly result from the fact that a private actor has exclusive access to certain input factors..$^{45}$ As a result, it is inter alia conceivable that under certain conditions data access rights are justifiable for the improvement of medical care, as is currently being discussed. ${ }^{46}$

When balancing the public or government interest in obtaining access to private data on the one hand and the interests of a private data owner in maintaining secrecy on the other hand, it is certainly also important to consider the extent to which the existence of the data in question is the re-

44 German Federal Constitutional Court, 8 April 1987, Case 2 BvR 909/82, 108 Entscheidungen des Bundesverfassungsgerichts 75, 108, 154-158; 6 June 1989, Case 1 921/85, 80 Entscheidungen des Bundesverfassungsgerichts 137, 153, 159161; 9 March 1994, Case 2 BvL 43/92, 90 Entscheidungen des Bundesverfassungsgerichts 145, 172-173; Christian Hillgruber, 'Grundrechtlicher Schutzbereich, Grundrechtsausgestaltung und Grundrechtseingriff in Josef Isensee und Paul Kirchhof (eds), Handbuch des Staatsrechts, Vol. IX ( $3^{\text {rd }}$ edn, C.F. Müller 2011) \$201, paras 51-77; Dreier (n. 4) Vor Art. 1 paras 145-149; Höfling (n. 4) Vor Art. 1 para. 135, Art. 20 GG paras 146, 149-157; von Münch and Kunig (n. 10) Vor Art. 1 para. 38.

45 See Andreas Schirra, Die Indienstnahme Privater im Lichte des Steuerstaatsprinzips (Peter Lang 2002) 32. In general, concerning the involvement of private parties to fulfil public tasks, cf. German Federal Constitutional Court, 16 March 1971, Case 1 BvR 52/66, 30 Entscheidungen des Bundesverfassungsgerichts 292, 311; 29 November 1967, Case 1 175/66, 22 Entscheidungen des Bundesverfassungsgerichts 380, 385; 22 January 1997, Case 2 1915/91, 95 Entscheidungen des Bundesverfassungsgerichts 173, 187; 17 February 1997, Case 1 33/76, 44 Entscheidungen des Bundesverfassungsgerichts 103, 103-104; 17 October 1984, Case $1 \mathrm{BvL}$ 18/82, 68 Entscheidungen des Bundesverfassungsgerichts 155, 170.

46 Cf. Torsten Körber, “Digitalisierung” der Missbrauchsaufsicht durch die 10. GWB-Novelle' (2020) Zeitschrift für IT-Recht und Recht der Digitalisierung 290, 292; Josef Drexl, 'Neue Regeln für die Europäische Datenwirtschaft?' (2017) Neue Zeitschrift für Kartellrecht 415, 416. 
sult of the exercise of a freedom protected by fundamental rights in the past and to what extent said data will be important for its owners when exercising their fundamental freedoms in the future. Moreover, even if one were to agree that the establishment of data access rights can generally be constitutionally justified under certain circumstances, the actual access may only be permissible in return for financial compensation. ${ }^{47}$

Finally, additional limits on the state's access rights to data of private individuals can result from legally protected interests of third parties when it comes to access to their data which is held by another private individual. This may even be true where such data is not personal, e.g. when it is subject to intellectual property rights or where it contains business and trade secrets, which may exclude a right of access in individual cases. ${ }^{48}$ Data access rights of the state must not force a private party obliged to give access to violate the rights of third parties. In case of doubt, the state must seek access to such data from the primary source, meaning the affected third party.

\section{Private data access rights}

If the legislature wants to establish statutory data access for private individuals against one another, clearly this also encroaches on the fundamental rights of the individuals obliged to grant access. In this respect, the limits applicable to such rights are generally comparable to those applicable to data access rights of the government. Accordingly, they require a legal basis, have to pursue a legitimate goal and must be proportionate in relation to that goal.

The abovementioned protection of competition from 'data market power' can serve as such a legitimate goal. In this respect, the legislature is also authorised to create competition-protecting statutes concerning private le-

47 On the concept of compensatory regulations that define the contents and limits of basic rights see Axer (n. 32) Art. 14 para. 104; cf. German Federal Constitutional Court, 14.07.1981, Case 1 24/78, 58 Entscheidungen des Bundesverfassungsgerichts $137,150-151$.

48 Cf. the similiar limitations under Secs 5 and 6 of the Freedom of Information Act. Concerning Sec. 5 Freedom of Information Act see also Federal Administrative Court, 13 December 2018, Case 7 C 19/17, (2019) Neue Zeitschrift für Verwaltungsrecht 807, paras 41-42; Federal Administrative Court, 17 March 2016, Case 7 C 2/15, (2016) Neue Zeitschrift für Verwaltungsrecht 1014, para. 25, and concerning Sec. 6 Freedom of Information Act, Federal Administrative Court, 25 June 2015, Case 7 C 1/14, (2015) Neue Juristische Wochenschrift 3258, para. 29. 
gal relationships. ${ }^{49}$ Nonetheless, it is still necessary to thoroughly establish the proportionality of said statutes. In this context, the relevant questions are: Firstly, is the data access really suitable for preventing detriments to competition? Secondly, is the data access necessary to prevent such harm or are there less restrictive measures? Thirdly, is the data access appropriate regarding the fact that it may lead to a devaluation of investments in the development of data collections and therefore reduce future business opportunities if said data collection can no longer be used exclusively by the data owner? A distinction will also have to be made as to whether data access should be designed to depend on an abusive refusal to grant access by the data owner or whether it should also be possible without such an abuse. In the latter case, the constitutional requirements for the justification of a statutory data access right are certainly higher, since the party obliged to give access to data on the basis of its having refused access is in principle exercising fundamental legal freedoms. Finally, it must be considered how compensation for data access can be granted, because it seems to be clear that data access to private data by other private parties will generally speaking only be constitutional if the obliged party is compensated for granting access.

\section{Interim result}

In principle, the legislature is entitled to create statutory data access rights. However, such access needs to be justified, given the fact that it encroaches on the fundamental rights of the party obligated to grant access - largely irrespective of who is supposed to receive access. In this respect, it is also conceivable to enact data access rights in favour of private individuals in order to protect effective competition. However, these rights need to be weighed against the fundamental rights of the parties obliged to grant the access. The requirements for constitutional justification become higher the more the control over data by a private party is a result of the owners exercising their freedoms protected by the fundamental rights and the more

49 See Art. 74(1) no. 16 GG; on this Degenhart (n. 37) Art. 74 para. 65; Christian Seiler, in Volker Epping and Christian Hillgruber (eds), Beck-Online-Kommentar Grundgesetz ( $43^{\text {th }}$ edn, C.H. Beck 2020) Art. 74 para. 57; German Federal Constitutional Court, 14 March1990, Case KVR 4/88 (KG), (1990) Gewerblicher Rechtsschutz und Urheberrecht 702, 703. Referring to market dominance in data, cf. Sec. 18(3a) No. 4 German Act against Restraints of Competition. 
the denial to give access to this data serves the future exercise of the freedoms protected by these fundamental rights.

\section{F. Final result}

The constitution provides a framework for data access rights that limits the legislature in terms of the chosen motive and its specific design, but also leaves considerable leeway. The legislature has a general authority to establish data access rights if they are proportionate. A general duty to establish such rights, however, does not exist. Only in extraordinary circumstances can the legislative authority be transformed into a legislative duty if data monopolists are able to hinder competition effectively and permanently in such a way that the respective market is no longer contestable. 
